\section{Research Square}

\title{
How plant production in the Mongolian grasslands is affected by wind-eroded coarse-textured topsoil
}

Kaman Kong ( $\nabla$ kong.kaman@h.mbox.nagoya-u.ac.jp )

Nagoya University https://orcid.org/0000-0003-2752-9716

Banzragch Nandintsetseg

National University of Mongolia

Masato Shinoda

Nagoya Daigaku

Research article

Keywords: DA Y CENT ecosystem model, Mongolian grasslands, Nitrogen stress, Plant production, Soil texture change, Temperature stress, Water stress, Wind erosion

Posted Date: April 9th, 2020

DOI: https://doi.org/10.21203/rs.3.rs-21040/v1

License: (c) (i) This work is licensed under a Creative Commons Attribution 4.0 International License.

Read Full License

Version of Record: A version of this preprint was published at Journal of Arid Environments on June 1st, 2021. See the published version at https://doi.org/10.1016/j.jaridenv.2021.104443. 


\section{How plant production in the Mongolian grasslands is}

\section{2 affected by wind-eroded coarse-textured topsoil}

3 Kaman Kong ${ }^{1}$

4 Corresponding author

$5 \quad$ Email: kong.kaman@h.mbox.nagoya-u.ac.jp

6

7 Banzragch Nandintsetseg ${ }^{1,2} \& 3$

$8 \quad$ Email: nandiad98@gmail.com

10 Masato Shinoda ${ }^{1}$

11 Email: shinoda.masato@g.mbox.nagoya-u.ac.jp

13 (Institutional addresses)

14 1. Graduate School of Environmental Studies, Nagoya University, Furo-cho, Chikusa-ku,

15 Nagoya, Aichi, 464-8601, Japan

2. Information and Research Institute of Meteorology, Hydrology, and Environment,

17 Ulaanbaatar, 15160, Mongolia

3. School of Arts and Sciences, National University of Mongolia, Ulaanbaatar, 210646,

19 Mongolia 


\section{Abstract}

22 While it is known that soil erosion by wind in drylands results in soil loss and redistribution

23 and changes the texture of topsoil, there is little information about how these changes in the

24 topsoil might affect the productivity of vegetation and if they result in degradation of the

25 grasslands in wind-eroded regions such as Mongolian grasslands. In this study, we compared

26 two different scenarios of vegetation growth, namely a wind-eroded scenario and an actual

27 field condition, on two different grasslands in Mongolia (steppe and desert steppe) using an

28 ecosystem model. The simulations of the wind-eroded scenario were based on a topsoil ( $0-0.1$

29 m depth) with $1 \%$ clay and $99 \%$ sand, designed to represent an extremely wind-eroded soil

30 surface that had permanently lost the fine clay particles and had gained sand particles. The

31 effects of temperature, nutrient and water stresses on plant production were quantitively

32 estimated. The model gave reasonably good simulations of the vegetation and soil water

33 dynamics during the growing seasons (April-September) from 2002-2011. The simulation

34 results showed that water had more effect on plant production than nitrogen and temperature

35 at the two sites, and stresses because of a lack of water and nutrients generally affected plant

36 production in the wind-eroded coarse-textured topsoil. Plant production was $20.2 \%$ lower in

37 the wind-eroded scenario than in the actual field condition in the desert steppe under water-

38 stressed conditions but plant production was slightly higher (5.0\%) in the wind-eroded 
scenario on the steppe that received more rainfall, because of a reverse texture effect, where

water continues to infiltrate from the coarse topsoil ( $0-0.1 \mathrm{~m}$ depth) to the deeper root-zone

(0.1-0.3 m depth) because of lower evapotranspiration from soil, and facilitates growth.

When this happens, there is enough soil moisture in the root-zone, and plant growth is mostly affected by the nitrogen supply.

\section{Keywords}

DAYCENT ecosystem model, Mongolian grasslands, Nitrogen stress, Plant production, Soil

\section{Introduction}

50 The area of degraded land in dryland areas is increasing at an alarming pace, threatening food security and environmental quality (UNCCD, 1994). Soil erosion, mainly by wind and water, occurs in arid and semi-arid regions worldwide (Shao, 2008; Shinoda et al., 2011). Soil that is eroded by strong wind causes aeolian dust events that threaten human and livestock health, present risks to life, and cause environmental problems, such as land degradation and air pollution, and economic losses in both the source and downwind areas. These phenomena 
et al., 2013; Shao et al., 2011). Over recent decades, aeolian dust events have become increasingly severe globally, including those on temperate grasslands (Shinoda et al., 2011; Shao and Dong, 2006; Chimgee et al., 2010). Of the total land area affected by wind erosion worldwide, 549 million hectares are in major dust source regions (Middleton and Thomas, 1997), some of which are in northeastern Asia (Shinoda et al., 2014; Nandintsetseg and Shinoda, 2015). These phenomena affect ecosystems at different scales and facilitate important biophysical feedbacks between biotic and abiotic components of Earth systems (Ravi et al., 2010; Shao et al., 2011), particularly the interactions between wind erosion and vegetation dynamic processes in dryland. Plant growth is generally affected by environmental factors such as temperature, light, water, and nutrients, which, when they deviate from the optimal intensity or quantity for the plant, are called stress factors (Schulze et al., 2005). Water is the factor that most limits plant productivity, and studies have shown that growth rates are proportional to

71 water availability when the temperature is suitable for plant growth in arid and semi-arid regions (Noy-Meir, 1973; Pugnaire et al., 1999). Furthermore, productivity may be limited under temperature extremes and low soil nutrient contents (Fischer and Turner, 1978). During

74 wind erosion, fine particles $(<125 \mu \mathrm{m})$ in the topsoil are permanently removed from the parent soil surface and are redistributed elsewhere by aerodynamic lift, saltation bombardment, and

76 disaggregation (Shao et al., 1993; Shao, 2008; Kok et al., 2012; Újvári et al., 2016; Zhang et 

al., 2016). At the same time, the texture of the topsoil becomes increasingly coarse (Li et al., 2009; Yan et al., 2018) because of the accumulation of large amounts of sand-sized particles that hop along the topsoil by saltation (Shao, 2008) from the windward side. Consequently, when topsoil is eroded by strong wind, the texture, and also the soil water status and nutrients content are changed, and may cause plant productivity to decrease (Kirchner 1977; Larney et al., 1998; Hooper and Johnson., 1999; Okin et al., 2004; Harpole et al., 2007) or increase

83 (Alizai and Hulbert, 1970; Noy-Meir, 1973; Sala et 1998). However, there is little information

84 about how wind erosion accelerates land degradation in drylands through interactions with 85 vegetation.

86 The coarser eroded soil in the top layer has less ability to retain water because of a decrease in 87 the water-holding capacity (Saxton et al., 1986; Saxton and Rawls., 2006; Zhao et al., 2006) and an increase in the saturated hydraulic conductivity of the soil (Yao et al., 2013). This means that the water supply to the plant may be limited, causing an increase in water stress

90 and effects on plant production (Pugnaire et al., 1999; Porporato et al., 2001). Conversely,

91 previous field studies reported that there was more evaporation from fine-textured than from

92 coarse-textured soils in arid and semi-arid areas (Alizai and Hulbert, 1970; Noy-Meir, 1973).

93 This effect may effectively trigger competition for moisture in the root-zone and lead to a

94 decrease in the effect of water stress on plant production (Noy-Meir, 1973). In addition, some 95 recent field studies and simulations have shown that wind erosion plays an important role in 
the depletion and redistribution of soil organic carbon (SOC) and a variety of soil nutrients

111 (Mandakh et al., 2007), triggered by climate change and overgrazing (Nandintsetseg et al.,

112 2018). Indeed, the situation is so serious that the Mongolian grasslands are recognized as one

113 of the most vulnerable terrestrial ecosystems to wind erosion worldwide under a changing

114 climate (Kassas, 1995; Lal, 2003; Shinoda et al., 2011; Abulaiti et al., 2014). 
115 In this study, we examined how plant productivity differed between wind-eroded coarse-

116 textured topsoil (0-0.1 m depth) and actual field conditions on two different Mongolian

117 grasslands (steppe and desert steppe). To do this, we simulated and compared the growth on

118 the potentially wind-eroded coarse-textured topsoil (referred to as the wind-eroded scenario)

119 and the actual field condition (referred to as the actual condition). We therefore used an

120 ecosystem model (DAYCENT) to study the daily vegetation dynamics for both conditions at

121 these two grasslands, and quantitatively estimated how much of the change in plant

122 production was attributable to the limited supplies of water and nutrients (nitrogen).

\section{Materials and methods}

\section{Study area description}

126 The two study sites are on the Mongolian grasslands (Fig. 1). One site, Bayan-Unjuul (BU:

$12747.04^{\circ} \mathrm{N}, 105.95^{\circ} \mathrm{E}$ ), is on the steppe and has a semi-arid climate while the other, Tsogt-Ovoo

128 (TsO: $44.42^{\circ} \mathrm{N}, 105.39^{\circ} \mathrm{E}$ ) is on the desert steppe and has an arid climate. The two sites are in

129 the north (BU) and the middle (TsO) of a major dust source area (Shinoda et al., 2011;

130 Kurosaki et al., 2007; Kurosaki et al, 2011), respectively. It was assumed that vegetation was

131 critical for dust emissions in temperate grasslands, so the Dust-Vegetation Interaction

132 Experiment (DUVEX) was established at BU in 2007 to gain insights into the relationships

133 between dust emissions and ecosystem processes (e.g. vegetation, soil moisture, and grazing) 
134 on vegetated land surfaces (Shinoda et al., 2010; Nandintsetseg and Shinoda, 2015). The

135 DUVEX project was extended to include a dust observation site at TsO (Ishizuka et al., 2012;

136 Abulaiti et al., 2014). Weather information was obtained from the Mongolian Institute of

137 Meteorology, Hydrology, and the Environment (IRIMHE) for the period from 2002-2011 at

138 BU and from 2002-2017 at TsO. The average annual precipitation at BU and TsO amounted

139 to 145.1 and $85.3 \mathrm{~mm}$, with 116.9 and $71.5 \mathrm{~mm}$ occurring between May and September,

140 respectively. The annual mean temperatures at $\mathrm{BU}$ and $\mathrm{TsO}$ were $0.86^{\circ} \mathrm{C}$ and $5.1^{\circ} \mathrm{C}$,

141 respectively. At both sites, the soil is frozen during winter (October-March), and the growing

142 season generally begins in late April and lasts until mid-September. The Mongolian grasslands

143 are generally dominated by the C3 vegetation type (Nandintsetseg and Shinoda, 2015). At

144 BU, natural perennial grasses (Stipa krylovii, Stipa grandis, and Cleistogenes squarrosa),

145 forbs (Artemissia spp.), and small shrubs (Caragana spp.) dominate, while desert shrubs

146 (Reaumuria soongolica and Salsola passerine) dominate at TsO (Hilbig, 1995; Ishizuka et al.,

147 2012).

148

149 Simulations for the actual and wind-eroded scenarios

150 The aim of the simulations was to examine how the plant productivity changed in the wind-

151 eroded coarse-textured topsoil in the Mongolian grasslands. For the wind-eroded scenario, a

152 topsoil (0-0.1 m depth) that comprised $1 \%$ clay and $99 \%$ sand was used. This represented a 
153 soil had permanently lost most of the fine clay particles from its surface because of dust

154 emissions by aerodynamic entrainment, saltation bombardment and aggregate disintegration

155 (Shao, 2008; Kok et al., 2012; Újvári et al., 2016; Zhang et al., 2016), leaving coarse sandy

156 particles that were supplemented through saltation (Shao, 2008) from the windward side. This

157 type of texture may be common in topsoils in severely degraded grasslands, particularly these

158 Mongolian grasslands, that eroded by wind. The simulations of the actual field condition were

159 based on the observed data of the soil texture at the steppe and desert steppe field sites (Table

$1601)$.

161

162 Meteorological data and land surface measurements

163 The meteorological (daily maximum and minimum air temperatures, and daily precipitation)

164 data from the IRIMHE monitoring stations at BU (1980-2011) and TsO (1980-2016) were

165 used as model inputs. The above-ground mass (AGM) (live plus standing dead grasses) in the

166 grazing areas of BU was measured approximately monthly in June, July, and August (mostly

167 August) from 2003 to 2010 (Nandintsetseg and Shinoda, 2015). Measurements of AGM

168 (2002-2015) in the grazing areas at the TsO IRIMHE monitoring station were also obtained.

169 Plants in $1 \times 1 \mathrm{~m}$ quadrants that were randomly distributed throughout the grazing areas were

170 clipped (Nandintsetseg and Shinoda, 2010). The stocking rates (number of animals per

171 hectare) at BU and TsO were classified as light grazing (Sugita et al., 2007) and heavy 
172 grazing, respectively. Soils at $\mathrm{BU}$ and $\mathrm{TsO}$ are mostly Kastanozems and Kastannozem calcic

173 skelectic (Kinugasa et al., 2012; Dordjgotov, 2003). The texture and bulk densities of the

174 topsoils at $\mathrm{BU}$ and $\mathrm{TsO}$ are shown in Table 1. The volumetric soil moisture content was

175 measured hourly at depths of 0.1 and $0.2 \mathrm{~m}$ at BU from 2004 to 2008 (Shinoda et al., 2010;

176 Nandintsetseg and Shinoda, 2015) and at TsO from 2012 to 2015 (Ishizuka et al., 2012) using

177 time-domain reflectometry. The field-measured data were used for the DAYCENT model

178 validations and simulations.

179

180 Model description

181 The DAYCENT model is a process based terrestrial ecosystem model that simulates how

182 fluxes of carbon, nutrients (e.g., nitrogen, phosphorus and sulfur), and trace gases in the

183 atmosphere, soil, and plants, change in response to human activities, such as fire and grazing

184 (Del Grosso et al., 2001; Parton et al., 1998). This model is the daily time-step version of the

185 CENTURY biogeochemical model (Parton et al., 1994), and includes routines for simulating

186 the movement of nutrients and water through soil layers, plant growth, and many other

187 ecosystem components. The model input variables include (1) climate variables (daily

188 maximum and minimum air temperature, and daily precipitation), (2) site-specific variables

189 such as soil properties (texture, depth, $\mathrm{pH}$, bulk density, and field capacity) (Table 1), and (3)

190 land management (e.g., cultivation or grazing). 
191 The plant production sub-model of DAYCENT (Parton et al., 1993, Kelly et al., 2000, and

192 Del Grosso et al., 2011) can simulate a variety of ecosystems, including grasslands (Gilmanov

193 et al., 1997; Nandintsetseg and Shinoda., 2015; Chang et al., 2015), by altering various plant-

194 specific parameters so that different herbaceous crops (corn, wheat, etc.) and plant

195 communities (C3, C4, etc.) are represented. This sub-model considers plant productivity as a

196 function of genetic potential, phenology, nutrient availability, water/temperature stress, and

197 solar radiation. Biomass can be removed or transferred to the litter pool by disturbances such

198 as grazing. The effect of grazing pressure on plant production was represented by the models

199 of Holland et al. (1992), Ojima et al. (1993), and Ojima and Correll (2009).

200 The widely-used soil water sub-model can simulate the soil moisture content and water fluxes

201 through the canopy, surface runoff, leaching, evaporation and transpiration for each horizon

202 throughout the defined depth of the soil layers (Parton et al., 1998, Eitzinger et al., 2000; Del

203 Grosso et al., 2011, Nandintsetseg and Shinoda, 2015). The amount of water in the soil that is

204 available for plant growth depends on the current soil water, precipitation, and potential

205 evapotranspiration (Parton et al., 1998). Precipitation intercepted by vegetation and litter is

206 evaporated at the PET rate calculated by the Penman equation (1948). The amount of water

207 intercepted is a function of the plant biomass and the amount of rainfall (Parton, 1978). When

208 the daily air temperature is below freezing, precipitation is assumed to fall as snow and is

209 accumulated in the snowpack. 
In addition, the soil organic matter and nutrient sub-models represent the flow of carbon (C),

211 nitrogen $(\mathrm{N})$, phosphorus $(\mathrm{P})$, and sulfur $(\mathrm{S})$ in plant litter, and different organic and inorganic

212 soil pools (Parton et al., 1988). The N sub-model, which has the same structure as the soil C

213 sub-model (Parton et al., 1994), was the focus of this study. The $\mathrm{N}$ flows are equal to the

214 product of the $\mathrm{C}$ flows and the $\mathrm{C} / \mathrm{N}$ ratio of the state variable that receives the $\mathrm{C}$. The inputs of

$215 \mathrm{~N}$ can be calculated using equations for atmospheric deposition, and soil and plant $\mathrm{N}$ fixation.

216 The $\mathrm{N}$ losses due to leaching are related to the soil texture and the amount of water moving

217 through the soil profile (Parton et al., 1994, 1996, 2001; Del Grosso et al., 2000).

219 Simulating water, temperature, and nitrogen stresses with the DAYCENT model

220 In the DAYCENT grassland sub-model, plant production is controlled by initially having soil

221 moisture and temperature at a maximum, and then decreased if the soil nutrient supply is

222 insufficient. The grassland model also includes the effect of shading from dead vegetation,

223 while the forest model includes the effect of live leaf area on plant production (Parton et al.,

224 1993). During the simulation processes, the maximum potential (or genetic maximum) above-

225 ground plant production $\left(A G P_{\max }\right)$, not limited by temperature, water, or nutrient stresses, is

226 primarily determined by the level of photosynthetically active radiation, the maximum net

227 assimilation rate of photosynthesis, the efficiency at which carbohydrates are converted into

228 plant constituents, and the rate at which respiration is maintained (van Heemst, 1986). Thus, 
the parameter for $A G P_{\max }$ has both genetic and environmental components. The potential

230 production $\left(A G P_{p o t}\right)$ is a function of the $A G P_{\max }$ for grassland and $0-1$ environmental scalars

231 depending on soil temperature, soil water status, shading from dead vegetation, and seedling

232 growth (Parton et al., 1993). Here, seedling growth and shading from dead vegetation will

233 have a negligible effect on $A G P_{p o t}$, because the seedling growth for grass is not limited

234 (Parton et al., 1992). Also, the shading effect on $A G P_{p o t}$ is a response surface that depends on

235 the amount of live and dead vegetation. We found that amounts of observed above-ground

236 live and dead vegetation in the Mongolian grasslands (Fig. 2) were lower than the threshold

237 values at which shading occurs and shoot senescence increases (150 and $60 \mathrm{~g} \mathrm{~m}^{-2}$,

238 respectively) (Parton et al., 1992). Therefore, we assumed that the soil water status and

239 temperature were the main controls on the $A G P_{p o t}$ in the Mongolian grasslands (Eq. 1). The

240 effects of soil water availability and temperature on plant production (Water stress, $W_{\text {stress }}$;

241 Temperature stress, $T_{\text {stress }}$ ) were calculated as shown in Eq. (2) and Eq. (3).

$$
A G P_{p o t}=A G P_{\max } \times S_{T} \times S_{w}
$$

$$
\begin{aligned}
& T_{\text {stress }}=1-S_{T} \\
& W_{\text {stress }}=1-S_{w}=1-\frac{\mathrm{AGP}_{\mathrm{pot}}}{\mathrm{AGP}_{\max } \times S_{T}}
\end{aligned}
$$

245 Where $S_{T}$ is an environmental scalar of soil temperature, which is calculated as a function of

246 air temperature and the optimum plant temperature. $S_{w}$ is an environmental scalar of soil

247 moisture statue, which is identified by the soil-water sub-model (Parton et al., 1993). The 
248 values of $T_{\text {stress }}$ and $W_{\text {stress }}$ are both range from 0 to 1 , and the values close to 1 indicate the

249 maximum stress on plant production.

250 The plant production also decreases if there is insufficient mineral nutrient for uptake and to

251 satisfy the $\mathrm{C} / \mathrm{N}$ ratio for producing plants. The actual production $\left(A G P_{\text {act }}\right)$ is limited to what

252 can be achieved with the nutrient supply available at the time with plant nutrient

253 concentrations Eq. (4). We assumed how the $A G P_{a c t}$ was affected by the lack of nitrogen

254 (nitrogen stress, $N_{\text {stress }}$ ) as shown in Eq. (5).

255

256

$$
A G P_{\text {act }}=A G P_{p o t} \times S_{N}
$$

$$
N_{\text {stress }}=1-S_{N}=1-\frac{A G P_{a c t}}{A G P_{p o t}}
$$

257 Where $S_{N}$ is an environmental scalar of nitrogen insufficiency, which is identified by the soil 258 organic matter and nutrient sub-models.

259 In this study, we mainly focused on the changes in the effects of $W_{\text {stress }}$ and $N_{\text {stress }}$ on $A G P_{\text {act }}$

260 for the actual condition and the wind-eroded scenario during the critical growing season

261 (June-August). Eq. (6), Eq. (7) and Eq. (8) were therefore proposed to examine coarse-

textured topsoil impacts on $A G P_{a c t}$ :

$$
\Delta A G P_{a c t}=\left(A G P_{a c t}\right)_{\text {eroded }}-\left(A G P_{\text {act }}\right)_{\text {actual }}
$$

266 Where $\Delta A G P_{a c t}, \Delta W_{\text {stress }}$, and $\Delta N_{\text {stress }}$ are the differences in the actual plant production, water 
267 stress, and nitrogen stress between the actual condition and the wind-eroded scenario. The

268 subscripts "actual" and "eroded" denote the actual condition and the wind-eroded scenario,

269 respectively.

270 The changes in the plant production between the actual condition and wind-eroded scenario

$271\left(\triangle A G P_{a c t}\right)$ were examined. For example, when $\triangle A G P_{a c t}<0$, the $A G P_{a c t}$ in the actual condition

272 was higher than in the wind-eroded scenario. The reasons for the changes in $\triangle A G P_{\text {act }}$ from the

$273 \Delta W_{\text {stress }}$ and the $\Delta N_{\text {stress }}$ were also analyzed. When $\Delta W_{\text {stress }}>0$ and $\Delta N_{\text {stress }} \leq 0$, plant production

274 is mainly limited by water, while when $\Delta W_{\text {stress }}<0$ and $\Delta N_{\text {stress }}>0$, plant growth is limited by

275 nitrogen.

276

277 Site-level model parameterization

278 Previous studies have shown that global grassland ecosystems can be simulated using

279 relatively few data of site-specific parameters that change as the circumstances change

280 (Parton et al., 1995; 1998). The DAYCENT model was parameterized and calibrated with the

281 field experiment data (soil physical and chemical properties, and vegetation) at BU

282 (Nandintsetseg and Shinoda, 2015) and TsO (Table. 1). AGP $_{\max }$, and the optimum and

283 maximum temperatures for production were parameterized using information from the

284 agrometeorological database for the Mongolian grasslands (IMH, 1996).

285 The soil and vegetation were in equilibrium for the actual condition and wind-eroded scenario 
at $\mathrm{BU}$ and $\mathrm{TsO}$, historical simulations were processed in DAYCENT for 1980 years by

repeating the long-term climate averages over 32 years (1980-2011) for BU and 37 years

model for the actual grazing condition (light grazing for BU from 1980 to 2011 and heavy

290 grazing for TsO from 1980 to 2016). The model performance was assessed from the mean

291 absolute deviation $\left(D_{\text {abs }}\right)$ and the slope coefficient $(b)$ from the regression equation of the

292 observations versus the corresponding simulations (Gilmanov et al., 1997).

294 Results

\section{Model performance}

296 The model performance of the actual condition was validated using observations of daily soil

297 moisture and above-ground mass (AGM) from April to September at BU and TsO. The daily

298 precipitation, and the daily observed and simulated soil moisture and AGM from 2002 to 2011

299 at BU and from 2002 to 2017 at TsO are shown in Fig. 2. In general, the model gave

300 reasonably good simulations of the daily variations in the soil moisture at both stations ( $r=$

$3010.80, p<0.05$ for BU, and $r=0.56, p<0.05$ for TsO) (Figs. $2-\mathrm{a} 1$ and $2-\mathrm{a} 2$ ). These

302 simulations of soil moisture at both sites showed a similar seasonal pattern as was observed in

303 a previous study of the Mongolian grasslands. There were three seasonal phases of soil

304 moisture, as follows: the spring drying between April and May until the onset of the rainy 
season, the summer recharge between late May and late July from summer precipitation, and autumn drying in August-October prior to the soil freezing because of the decrease in

307 precipitation (Nandintsetseg and Shinoda, 2011). The $D_{a b s}$ and $b$ of the observed soil moisture 308 data from these simulations were $1.8 \%$ and 1.2 at $\mathrm{BU}$, and $2.6 \%$ and 0.9 at TsO, respectively.

309 Comparison of the measured and simulated values shows that the model performed well using 310 the available observed data even though the observed and simulated soil moisture data were 311 from slightly different depths. The model gave a reasonable simulations of soil carbon and 312 total nitrogen at BU with $r=0.94(p<0.05)$ and $r=0.55(p<0.05)$ but the soil total nitrogen 313 was underestimated $(6.8 \%)$.

314 As shown in Figs. 2-b1 and 2-b2, there was good agreement between the daily simulated and 315 observed AGM at both sites $(r=0.77, p<0.05$ for BU, and $r=0.60, p<0.05$ for TsO). The 316 simulations of the seasonal dynamics in AGM showed the timings of the onset of spring 317 growth (May), a summer peak (July-August), and decay (September). The $D_{a b s}$ and $b$ of the 318 observed data from these simulations were $21.7 \mathrm{~g} \mathrm{~m}^{-2}$ and 1.5 at $\mathrm{BU}$, and $1.3 \mathrm{~g} \mathrm{~m}^{-2}$ and 0.7 at 319 TsO, respectively. The model underestimated the peak production in the years when the 320 measured production at BU was high (2003, 2008, and 2010) and following drought years at 321 TsO (2008), perhaps reflecting changes in the plant species composition during those years

322 (Nandintsetseg and Shinoda, 2015). Previous observed studies showed that annual plant 323 species increased more after drought years than perennial species (Shinoda et al., 2014). 
324 Numerous studies have shown that the grassland degradation has increased (Mandakh et al.,

325 2007; Nandintsetseg and Shinoda, 2013) and the plant species composition has decreased;

326 moreover, because of drought (Shinoda et al., 2014) and overgrazing in the Mongolian

327 grasslands in recent decades (e.g., Jigmed, 2006; Hilker et al., 2014; Nandintsetseg et al.,

328 2017), perennial species are being substituted by annual species. While the model only

329 focused on a whole plant community (C3 in this study), and did not consider changes in

330 species because of seasonal- and inter-annual variations and functional diversity of the plant

331 community (e.g., Parton et al., 1993; 1995), these results suggest that the DAYCENT model

332 can give reasonable simulations of seasonal and inter-annual changes in soil moisture and

333 AGM in the steppe and desert steppe ecosystems. Generally, the rainfall was higher (soil

334 moisture), and the evapotranspiration was lower, at BU (steppe) than at TsO (desert steppe).

335 The modelled and observed data therefore showed that the conditions were more favorable for

336 higher plant production at $\mathrm{BU}$ than at $\mathrm{TsO}$.

338 Effects of water, temperature, and nitrogen stresses on plant production in the

339 actual and wind-eroded scenarios

340 Figure 3 shows the monthly precipitation and temperature (a1, a2), and monthly simulated

$341 A G P_{a c t}, W_{\text {stress }}, T_{\text {stress }}$ and $N_{\text {stress }}$ values for the actual condition and the wind-eroded scenario at

342 TsO (b1, c1) and BU (b2, c2) in the growing season (May-September) for 2002-2011. The 
343 monthly average $A G P_{a c t}\left(\mathrm{gC} \mathrm{m}^{-2}\right)$ for the actual/wind-eroded scenarios were 7.4/6.9 (May),

344 7.6/7.9 (June-August), and 1.3/1.1 (September) for BU and 0.6/0.3, 0.5/0.45, and 0.5/0.3 for

345 TsO, respectively. At both sites, soil moisture had more effect on $A G P_{\text {act }}$ than soil temperature

346 and nitrogen. The $W_{\text {stress }}$ was higher at TsO than at $\mathrm{BU}$. At BU, the $W_{\text {stress }}$ for the actual/wind-

347 eroded scenarios were 0.673/0.674 (May), 0.918/0.917 (June-August), and 0.918/0.909

348 (September), respectively. At TsO, $W_{\text {stress }}$ was more than 0.9 from May to September for both

349 conditions and ranged from 0.925 to 0.998 (actual condition) and from 0.962 to 0.998 (wind-

350 eroded scenario). The $N_{\text {stress }}$ played an important role for $A G P_{a c t}$ in the onset of the growth

351 (May) and summer periods (June-August) at BU. For the actual/wind-eroded scenarios, the

352 values of $N_{\text {stress }}$ at BU were higher from May to August $(0.451 / 0.536)$, than they were in

353 September $(0.430 / 0.522)$. However, plant production at TsO was not affected by nitrogen.

354 Soil temperature had a negligible effect on $A G P_{a c t}$ from June to August at both sites. For the

355 actual/wind-eroded scenarios, the values of $T_{\text {stress }}$ at BU were $0.732 / 0.732$ for May,

$3560.083 / 0.083$ for June-August, and 0.677/0.677 for September, respectively. At TsO, the values

357 of $T_{\text {stress }}$ were $0.787 / 0.787$ for May, $0.057 / 0.057$ for June-August, and $0.733 / 0.733$ for

358 September, respectively. These results show that water and nitrogen stresses influenced plant

359 production in the critical growing season (June-August) in the Mongolian grasslands, and that

360 temperature stress was only important in the emergence (May) and senescence (September)

361 periods, respectively. Our results are consistent with a previous study on the Mongolian 
grasslands by Nandintsetseg and Shinoda (2011), who reported that the emergence coincided

363 as the trends in soil moisture changed from decreasing to increasing as temperature increased.

364 To assess how plant production was influenced by textural changes in the wind-eroded

365 topsoil, we compared the simulations of the actual condition and the wind-eroded scenario at

366 both sites from June to August. Figure 4 shows the differences of $A G P_{\text {act }}, W_{\text {stress }}$ and $N_{\text {stress }}$

367 between the actual condition and the wind-eroded scenario ( $\triangle A G P_{\text {act }}, \Delta W_{\text {stress }}$ and $\left.\Delta N_{\text {stress }}\right)$ in

368 the critical growing season from 2002 to 2011 (total 30 months) at $\mathrm{BU}$ and TsO. The $\triangle A G P_{\text {act }}$

369 at $\mathrm{BU}$ and $\mathrm{TsO}$ had mean values of $0.38(+5.0 \%)$ and $-0.14(-20.2 \%) \mathrm{gC} \mathrm{m}^{-2}$, respectively.

370 Table 2 shows that the $\triangle A G P_{\text {act }}$ was less than 0 for 10 months at $\mathrm{BU}$ and 28 months at TsO

371 while the $\triangle A G P_{\text {act }}$ was greater than 0 for 20 months at $\mathrm{BU}$ and 2 months in 2006 summer at

372 TsO. At TsO (Fig. 4-d1), plant production was mainly controlled by water $\left(\Delta W_{\text {stress }}>0\right.$ and

$\left.373 \Delta N_{\text {stress }} \leq 0\right)$ for 28 months when $\Delta A G P_{\text {act }}$ was less than 0 . Nitrogen $\left(\Delta W_{\text {stress }}<0\right.$ and $\Delta N_{\text {stress }}>$

374 0) was the main control on plant production for only 2 months during the summer of 2006 ,

375 which was wetter than normal, when $\triangle A G P_{\text {act }}$ was greater than 0 . This shows that plant

376 production decreased in the wind-eroded scenario at $\mathrm{TsO}$ generally, and this decrease was

377 caused by an increase in water stress. At BU (Fig. 4-d2), when $\triangle A G P_{a c t}$ was less than 0, plant

378 production was mainly controlled by water for 7 months, and by nitrogen for 2 months in

379 June 2002 and June 2003 because of the higher precipitation in previous month. When

$380 \triangle A G P_{a c t}$ was greater than 0 , plant production was primarily controlled by water for 5 months 
381 and by nitrogen for 14 months. The results show that this higher plant production at BU

$382(+5.0 \%)$ was mainly because the water stress decreased, and plant growth was thereafter

383 controlled by nitrogen in the critical growing season.

\section{Discussion}

386 When we compared the simulations of the $A G P_{\text {act }}$ between the actual condition and the wind-

387 eroded scenario, we found that plant production in the wind-eroded topsoil decreased by

$38820.2 \%$ in the desert steppe area (TsO) and slightly increased by $5.0 \%$ in the wetter steppe

389 (BU) during the critical growing season from 2002 to 2011. These results indicate that the

390 effects of the coarse-textured topsoil on the plant production may change with variations in

391 the environmental conditions in the Mongolian grasslands. In the desert steppe area, the

392 annual precipitation was lower (Fig. 5-a1) (between 38.2 and $164.5 \mathrm{~mm}$ from 2002 to 2011)

393 than at BU. In both scenarios, this precipitation did not penetrate into the deeper soil but was

394 stored in the topsoil layer (Figs. 5-a2 and 5-a3). The coarse topsoil meant that the water

395 holding capacity in the wind-eroded scenario was low, and the evapotranspiration was greater

396 than in the actual condition (Fig. 5-a4). Therefore, there was less soil moisture in the root-

397 zone (0.1-0.3 m depth) in the wind-eroded scenario than in the actual condition (Fig. 5-a5).

398 Previous studies have stated that biological processes in arid ecosystems with extremely low

399 precipitation were mainly controlled by water (Noy-Meir, 1973). Field studies have also 
shown that, when the available precipitation was less than $200 \mathrm{~mm}$, the productivity of natural

401 grass was low and did not differ significantly under different $\mathrm{N}$ fertilizer application rates

402 (Smike et al., 1965). Also, Nandintsetseg and Shinoda (2011) showed that the soil moisture

403 was below the Mongolian mean and close to the wilting point throughout the year in the

404 desert steppe. The soil available water, therefore, is the main influence on plant production in

405 arid ecosystems (Le Houerou et al., 1984; Lauenroth and Sala., 1992). At TsO, plant

406 production decreased in the wind-eroded scenario because of increased water stress, caused

407 by an increase in evapotranspiration and a decrease in the soil water in the root zone.

408 In contrast, in the wetter steppe (BU), the main reason for the slight increase in plant

409 production was a decrease in water stress. As shown in Fig. 5-b1, when the annual

410 precipitation ranged from 89.2 to $250.4 \mathrm{~mm}$ (from 2002 to 2011), more precipitation

411 penetrated into the deeper soil in the wind-eroded scenario, because of the lower water

412 holding capacity and higher hydraulic conductivity in the wind-eroded topsoil (Figs. 5-b2 and

413 5-b3). The evapotranspiration from the coarse topsoil in the wind-eroded scenario was

414 therefore lower than that from the loamy topsoil in the actual condition (Fig. 5-b4). Together,

415 these factors mean that there was more water in the root-zone to facilitate plant growth (Fig.

416 5-b5) in the wind-eroded scenario. Previous researchers have called this the inverse texture

417 hypothesis (e.g., Noy-Meir, 1973, Sala et al., 1988), and it has been observed in sandy regions

418 with relatively high precipitation $(<300 \mathrm{~mm})$. After adding equal amounts of water in 
often greater from a loam bare soil than from sand. Field studies (Sala et al., 1988; Yang et al.,

421 2009) have shown that the plant production was higher in sandy soils with lower water

422 holding capacity in wetter grasslands than in loamy soils with higher water holding capacity

423 on the Tibetan Plateau and the Central Grassland region of the US. Although the plant growth

424 is limited by the soil available water in semi-arid regions where inverse texture effects are

425 obvious, it is more sensitive to nitrogen stress when there is enough soil water during the

426 summer, as also reported elsewhere. From their field study, Hooper and Johnson (1999)

427 reported that plant production was limited by both water availability and nitrogen in a semi-

428 arid region, but that production responded positively to $\mathrm{N}$ additions as the water availability

429 increased. Also, Kinugasa et al. (2012) reported that, when $\mathrm{N}$ was added to the wetter steppe

430 soils at BU, had more effect on plant production in wetter years (when the water stress was

431 lower) than in drier years (when the water stress was higher).

432 Relatively few studies have discussed changes in vegetation because of changes in soil texture

433 driven by wind erosion as they occur slowly (Lyles, 1975, 1977; Larney et al., 1998), and may

434 only become noticeable after several years or decades. Previous studies found that the sand

435 content in surface soil increased by $6.5 \%$ and silt decreased by $7.2 \%$ over a 36 -year period

436 because of wind erosion (Kansas Lyles and Tatarko, 1986). Li et al. (2009) showed that fine

437 particles $(<125 \mu \mathrm{m})$ declined and sand particles $(>250 \mu \mathrm{m})$ increased significantly after two 
438 years in an area that was affected by serious wind-erosion. There may be a significant

439 decrease in the proportion of fine particles in surface soil that are enriched by higher amounts

440 of soil organic carbon and nutrients, as wind erosion progresses ( $\mathrm{Li}$ et al., 2007; Li et al.,

441 2009; Yan et al., 2018), which may then cause decreases in plant production in wind-eroded

442 regions. However, our results show that the decreases in plant production were mainly caused

443 by increases in water stress in wind-eroded topsoil at both sites on the Mongolian grasslands

444 (28 months at TsO and 6 months at BU). A field experiment in farmland in arid and semi-arid

445 regions in Inner Mongolia showed that soil that was subject to wind erosion since the 1980s

446 was significantly coarser, less fertile and drier than non-eroded land. Moreover, when high

447 amounts of sand accumulate (72.6\% sand), the average soil moisture content decreased

448 significantly (Zhao et al., 2006). These results imply that the soil water status may be affected

449 more than the soil nutrient pool in the wind-eroded coarse-textured topsoil in arid and semi-

450 arid regions.

451

452 Conclusions

453 In this study, we compared how the vegetation at two sites in steppe and desert steppe

454 Mongolian grassland landscapes differed between an extremely wind-eroded topsoil,

455 represented by the top $0.1 \mathrm{~m}$ comprising clay and sand contents of $1 \%$ and $99 \%$ (wind-eroded

456 scenario), and the actual grassland condition using an ecosystem model. The results from our 
study highlight the importance of identifying how temperature, soil moisture and nutrient

458 (nitrogen) stresses influence plant production in topsoil that might be eroded by wind in dust

459 source areas in the Mongolian grasslands. Moreover, this study provided new insights into

460 how plant production in arid and semi-arid regions is affected by wind-eroded soil and that

461 the soil water status may be affected more than the soil nutrient pool for decreases in plant

462 production as the topsoil becomes coarser as the wind erosion progresses.

463 Although natural wind-driven soil erosion processes occur slowly over several years or

464 decades, dust events, a major driver of land degradation worldwide, have increased in severity

465 over recent decades, because of climate change and human disturbances. Hence, realistic

466 changes in soil physical properties need to be considered when assessing how wind-driven

467 soil erosion affects the ecosystem carbon budget (Van Oost et al., 2007). This study will

468 contribute to current understanding of the potential effects of wind erosion on plant

469 production in dust source areas, and specifically about the particular stresses that vegetation in

470 wind-eroded arid and semi-arid grasslands are subjected to.

\section{Abbreviations}

473 AGM: Above-ground mass; AGP $_{\text {act: }}$ : Actual above-ground plant production; AGP $\max$ :

474 Maximum potential above-ground plant production; AGP $_{\text {pot }}$ : Potential above-ground plant

475 production; $b$ : The slope coefficient in the formal regression equation of the observed and 
476 simulated data; BU: Bayan-Unjuul; $D_{a b s}$ : Mean absolute deviation; MGs: Mongolian

477 Grasslands; $\mathrm{N}_{\text {stress: }}$ Nitrogen stress; RMSE: Root mean square error; TsO: Tsogt-Ovoo; $\mathrm{T}_{\text {stress: }}$ :

478 Temperature stress; $\mathrm{W}_{\text {stress: }}$ : Water stress; $\Delta \mathrm{AGP}_{\text {act: }}$ : The difference in the actual above-ground

479 plant production between the actual condition and the wind-eroded scenario; $\Delta \mathrm{N}_{\text {stress: }}$ : The

480 difference in the nitrogen stress between the actual condition and the wind-eroded scenario;

$481 \Delta \mathrm{W}_{\text {stress: }}$ The difference in the water stress between the actual condition and the wind-eroded

482 scenario

483

484 Declarations

485 Availability of data and material

486 Data sharing not applicable to this article as no datasets were generated or analysed during the

487 current study. Please contact author for data requests.

488

489 Competing interests

490 The authors declare that they have no competing interest

491

$492 \quad$ Funding

493 This study was supported by the Japan Society for the Promotion of Science (JSPS) (Grant

494 No. 25220201). 


\section{Authors' contributions}

$497 \mathrm{KK}, \mathrm{BN}$, and MS proposed the topic and conceived and designed the study. KK and BN

498 analyzed the data. All authors contributed to writing the manuscript. All authors read and

499 approved the final manuscript.

500

501 Authors' information

$502{ }^{1}$ Graducate School of Environmental Studies, Nagoya University, Furo-cho, Chikusa-ku,

503 Nagoya, Aichi, 464-8601, Japan. ${ }^{2}$ Information and Research Institute of Meteorology,

504 Hydrology, and Environment, Ulaanbaatar, 15160, Mongolia. ${ }^{3}$ School of Arts and Sciences,

505 National University of Mongolia, Ulaanbaatar, 210646, Mongolia.

506

507 Acknowledgements

508 We thank Dr. Yasunori Kurosaki and Dr. Bat-Ouyn for providing the datasets of soil moisture

509 and biomass for 2012-2015 at the Tsogt-Ovoo station. This research was supported by the

510 Japan Society for the Promotion of Science (JSPS) (Grant No. 25220201). We thank Edanz

511 Group (www.edanzediting.com/ac) for editing a draft of this manuscript. 


\section{References}

513 Abulaiti A, Kimura R, Shinoda M, Kurosaki Y, Mikami, M, Ishizuka M, Yamada Y, Nishihara

514 E, Gantsetseg B (2014) An observational study of saltation and dust emission in a hotspot of

515 Mongolia. Aeolian Res 15:169-176. doi:10.1016/j.aeolia.2014.05.002

516 Alizai HU, Hulbert LC (1970) Effects of soil texture on evaporative loss and available water

517 in semi-arid climates. Soil Sci 110(5):328-332. doi:10.1097/00010694-197011000-00006

518 Chang X, Bao X, Wang S, Wilkes A, Erdenetsetseg B, Baival B, Avaadorj D, Maisaikhan T,

519 Damdinsuren B (2015) Simulating effects of grazing on soil organic carbon stocks in

520 Mongolian grasslands. Agric Ecosyst Environ 212:278-284. doi:10.1016/j.agee.2015.07.014

521 Chimgee D, Shinoda M, Tachiiri K, Kurosaki Y (2010) Why did a synoptic storm cause a

522 dramatic damage in a limited area of Mongolia. Mongolian Population J 19: 63-8.

523 Del Grosso SJ, Parton WJ, Keough CA, Reyes-Fox M (2011) Special features of the DayCent

524 modeling package and additional procedures for parameterization, calibration, validation, and

525 applications. In Ahuja LR, Ma L (ed) Methods of introducing system models into agricultural

526 research. American Society of Agronomy, Madison, 155-176.

527 Del Grosso SJ, Parton WJ, Mosier AR, Hartman MD, Keough CA, Peterson GA, Ojima DS,

528 Schimel DS (2001) Simulated effects of land use, soil texture, and precipitation on N gas

529 emissions using DAYCENT. In Follett RF, Hatfield (ed) Nitrogen in the Environment:

530 Sources, Problems and Management. Elsevier Science, pp 413-431. 
531 Del Grosso SJ, Parton WJ, Mosier AR, Ojima DS, Kulmala AE, Phongpan S (2000) General

532 model for $\mathrm{N}_{2} \mathrm{O}$ and $\mathrm{N}_{2}$ gas emissions from soils due to dentrification. Global Biogeochem

533 Cycles 14(4): 1045-1060. doi:10.1029/1999GB001225

534 Dordjgotov D (2003) Soil of Mongolia [in Mongolian]. Admon, Ulaanbaatar.

535 Eitzinger J, Parton WJ, Hartman M (2000) Improvement and validation of a daily soil

536 temperature submodel for freezing/thawing periods. Soil Sci 165(7):525-534.

537

doi:10.1097/00010694-200007000-00001

538 Fischer RA, Turner NC (1978) Plant productivity in the arid and semiarid zones. Ann Rev

539 Plant Physiol 29(1): 277-317.

540 Gilmanov TG, Parton WJ, Ojima DS (1997) Testing the 'CENTURY'ecosystem level model

541 on data sets from eight grassland sites in the former USSR representing a wide climatic/soil

542 gradient. Ecol Model 96(1):191-210. doi:10.1016/S0304-3800(96)00067-1

543 Harpole WS, Potts DL, Suding KN (2007) Ecosystem responses to water and nitrogen

544 amendment in a California grassland. Glob Chang Biol 13(11):2341-2348.

545 doi:10.1111/j.1365-2486.2007.01447.x

546 Hilbig W (1995) Vegetation of Mongolia. SPB Academic Publishing, Ulaanbaatar.

547 Hilker T, Natsagdorj E, Waring RH, Lyapustin A, Wang Y (2014) Satellite observed

548 widespread decline in Mongolian grasslands largely due to overgrazing. Glob Chang Biol

549 20(2):418-428. doi:10.1111/gcb.12365 
550 Hoffmann C, Funk R, Li Y, Sommer M (2008) Effect of grazing on wind driven carbon and

551 nitrogen ratios in the grasslands of Inner Mongolia. Catena 75(2):182-190.

552 doi:10.1016/j.catena.2008.06.003

553 Holland EA, Parton WJ, Detling JK, Coppock DL (1992) Physiological responses of plant

554 populations to herbivory and their consequences for ecosystem nutrient flow. Amer Nat

555 140(4):685-706. doi:10.1086/285435

556 Hooper DU, Johnson L (1999) Nitrogen limitation in dryland ecosystems: responses to

557 geographical and temporal variation in precipitation. Biogeochemistry 46(1-3):247-293.

558 doi:10.1007/BF01007582

559 Ikazaki K, Shinjo H, Tanaka U, Tobita S, Funakawa S, Iwai K, Kosaki T (2012) Soil and

560 nutrient loss from a cultivated field during wind erosion events in the Sahel, West Africa.

561 Pedologist 55(3): 355-363. doi:10.18920/pedologist.55.3_355

562 Institute of Meteorology and Hydrology (IMH) (1996) Reference Book of

563 Agrometeorological Meteorology [in Mongolian]. NAMHEM, Ulaanbaatar.

564 Ishizuka M, Mikami M, Yamada Y, Kimura R, Kurosaki Y, Jugder D, Gantsetseg B, Cheng Y,

565 Shinoda M (2012) Does ground surface soil aggregation affect transition of the wind speed

566 threshold for saltation and dust emission?. Sola 8:129-132. doi:10.2151/sola.2012-032

567 Jigmed G (2006) The current situation of grassland resources in Mongolia. Bull Facul Agric

568 Niigata Univ 58(2):133-136. 
569 Kassas M (1995) Desertification: a general review. J Arid Environ 30(2):115-128.

570 doi:10.1016/S0140-1963(05)80063-1

571 Kelly RH, Parton WJ, Hartman MD, Stretch LK, Ojima DS, Schimel DS (2000) Intra-annual

572 and interannual variability of ecosystem processes in shortgrass steppe. J Geophys Res.

573 Atmos 105(D15):20093-20100. doi:10.1029/2000JD900259

574 Kinugasa T, Tsunekawa A, Shinoda M (2012) Increasing nitrogen deposition enhances post-

575 drought recovery of grassland productivity in the Mongolian steppe. Oecologia 170(3):857-

576 865. doi:10.1007/s00442-012-2354-4

577 Kok JF, Parteli EJ, Michaels TI, Karam DB (2012) The physics of wind-blown sand and dust.

578 Rep Prog Phys: 75(10): 106901. doi:10.1088/0034-4885/75/10/106901

579 Kirchner TB (1977) The effects of resource enrichment on the diversity of plants and

580 arthropods in a shortgrass prairie. Ecology:1334-1344. doi:10.2307/1935085

581 Kurosaki Y, Mikami M (2007) Threshold wind speed for dust emission in East Asia and its

582 seasonal variations. J Geophys Res Atmos: 112(D17). doi:10.1029/2006JD007988

583 Kurosaki Y, Shinoda M, Mikami M (2011) What caused a recent increase in dust outbreaks

584 over East Asia?. Geophys Res Lett :38(11). doi:10.1029/2011GL047494

585 Lal R (2001) Soil degradation by erosion. Land Degrad Dev 12(6):519-539.

586 doi:10.1002/ldr.472 
587 Lal R (2003) Soil erosion and the global carbon budget. Environ Int 29(4):437-450.

588 doi:10.1016/S0160-4120(02)00192-7

589 Larney FJ, Bullock MS, Janzen HH, Ellert BH, Olson EC (1998) Wind erosion effects on

590 nutrient redistribution and soil productivity. J Soil Water Conserv 53(2):133-140.

591 Lauenroth WK, Sala OE (1992) Long-term forage production of North American shortgrass

592 steppe. Ecol Appl 2(4):397-403. doi:10.2307/1941874

593 LeBauer DS, Treseder KK (2008) Nitrogen limitation of net primary productivity in terrestrial

594 ecosystems is globally distributed. Ecology 89(2):371-379. doi:10.1890/06-2057.1

595 Le Houérou HN (1984) An outline of the bioclimatology of Libya. Bulletin de la Société

596 Botanique de France. Bull Soc bot Fr 131(2-4):157-178.

597 doi:10.1080/01811789.1984.10826657

598 Li F, Zhao W, Liu J, Huang Z (2009) Degraded vegetation and wind erosion influence soil

599 carbon, nitrogen and phosphorus accumulation in sandy grasslands. Plant Soil 317(1-2):79.

600 doi:10.1007/s11104-008-9789-8

601 Li F, Zhao L, Zhang H, Zhang T, Shirato Y (2004) Wind erosion and airborne dust deposition

602 in farmland during spring in the Horqin Sandy Land of eastern Inner Mongolia, China. Soil

603 Tillage Res 75(2):121-130. doi.org/10.1016/j.still.2003.08.001 
604 Li J, Okin GS, Alvarez L, Epstein H (2007) Quantitative effects of vegetation cover on wind 605 erosion and soil nutrient loss in a desert grassland of southern New Mexico, USA.

606 Biogeochemistry 85(3):317-332. doi:10.1007/s10533-007-9142-y

607 Lyles L (1975) Possible effects of wind erosion on soil productivity. J Soil Water Conserv 608 30(6): 279-283.

609 Lyles, L. (1977) Wind erosion: processes and effect on soil productivity. Transactions of the 610 ASAE 20(5): 880-0884. doi:10.13031/2013.35668

611 Lyles L, Tatarko J (1986) Wind erosion effects on soil texture and organic matter. J Soil Water 612 Conserv 41(3):191-193.

613 Mandakh N, Dash D, Khaulenbek A (2007) Present status of desertification in Mongolia.

614 Geoecological issues in Mongolia 6:63-73.

615 Middleton N, Thomas D (1997) World atlas of desertification. Arnold, London

616 Nandintsetseg B, Shinoda M (2011) Seasonal change of soil moisture in Mongolia: its

617 climatology and modelling. Int J Climatol 31(8): 1143-1152. doi.org/10.1002/joc.2134

618 Nandintsetseg B, Shinoda M (2013) Assessment of drought frequency, duration, and severity

619 and its impact on pasture production in Mongolia. Nat Hazards 66(2):995-1008.

620 doi:10.1007/s11069-012-0527-4 
621 Nandintsetseg B, Shinoda M (2015) Land surface memory effects on dust emission in a

622 Mongolian temperate grassland. J Geophys Res Biogeosci 120(3):414-427.

623 doi:10.1002/2014JG002708

624 Nandintsetseg B, Shinoda M, Du C, Munkhjargal E (2018) Author Correction: Cold-season

625 disasters on the Eurasian steppes: Climate-driven or man-made. Sci Rep 8(1):15905.

626 doi:10.1038/s41598-018-33046-1

627 Nandintsetseg B, Shinoda M, Erdenetsetseg B (2017) Contributions of multiple climate

628 hazards and overgrazing to the 2009/2010 winter disaster in Mongolia. Nat Hazards 92:S109-

629 S126. doi:10.1007/s11069-017-2954-8

630 Nandintsetseg B, Shinoda M, Kimura R, Ibaraki Y (2010) Relationship between soil moisture

631 and vegetation activity in the Mongolian steppe. Sola 6:29-32. doi:10.2151/sola.2010-008

632 Noy-Meir I (1973) Desert ecosystems: environment and producers. Annu rev ecol syst

$6334(1): 25-51$.

634 Ojima DS. Corell RW (2009) Managing grassland ecosystems under global environmental

635 change: Developing strategies to meet challenges and opportunities of global change. In

636 Franzluebbers AJ (ed) Farming With Grass: Achieving Sustainable Mixed Agricultural

637 Landscapes. Soil and Water Conservation Society, Ankeny, pp 146-155. 
638 Ojima DS, Dirks BO, Glenn EP, Owensby CE, Scurlock JO (1993) Assessment of C budget

639 for grasslands and drylands of the world. Water Air Soil Pollut 70(1-4):95-109.

640 doi:10.1007/BF01104990

641 Okin GS, Mahowald N, Chadwick OA, Artaxo P (2004) Impact of desert dust on the

642 biogeochemistry of phosphorus in terrestrial ecosystems. Glob Biogeochem Cycles 18(2).

643 doi:10.1029/2003GB002145

644 Parton WJ, Hartman M, Ojima D, Schimel D (1998) DAYCENT and its land surface

645 submodel: description and testing. Glob Planet Chang 19(1):35-48. doi:10.1016/S0921-

646 8181(98)00040-X

647 Parton WJ, Holland EA, Del Grosso S J, Hartman MD, Martin RE, Mosier AR, Ojima DS,

648 Schimel DS (2001) Generalized model for NO x and N2O emissions from soils. J Geophys

649 Res Atmos 106(D15):17403-17419. doi:10.1029/2001JD900101

650 Parton WJ, McKeown B, Kirchner V, Ojima DS (1992) CENTURY Users Manual. Colorado

651 State University NREL Publication, Fort Collins, CO.

652 Parton WJ, Ojima DS, Cole CV, Schimel DS (1994) A general model for soil organic matter

653 dynamics: sensitivity to litter chemistry, texture and management. In: Bryant RB, Arnold RW

654 (eds) Quantitative modeling of soil forming processes: proceedings of a symposium

655 sponsored by Divisions S-5 and S-9 of the Soil Science Society of America in Minneapolis,

656 Minnesota, 1992. 
657 Parton WJ, Scurlock JMO, Ojima DS, Gilmanov TG, Scholes RJ, Schimel DS, Kirchner T,

658 Menaut J-C, Seastedt T, Garcia Moya E, Kamnalrut A, Kinyamario JI (1993) Observations

659 and modeling of biomass and soil organic matter dynamics for the grassland biome

660 worldwide. Glob biogeochem cycles 7(4):785-809. doi:10.1029/93GB02042

661 Parton WJ, Scurlock JMO, Ojima DS, Schimel DS, Hall DO (1995) Impact of climate change

662 on grassland production and soil carbon worldwide. Glob Chang Biol 1(1):13-22.

663 doi:10.1111/j.1365-2486.1995.tb00002.x

664 Parton WJ, Singh JS, Coleman DC (1978) A model of production and turnover of roots in

665 shortgrass prairie. J Appl Ecol 515-541. doi:10.2307/2402608

666 Parton WJ, Stewart JW, Cole CV (1988) Dynamics of C, N, P and S in grassland soils: a

667 model. Biogeochemistry 5(1):109-131. doi:10.1007/BF02180320

668 Parton WJ, Mosier AR, Ojima DS, Valentine DW, Schimel DS, Weier K, Kulmala AE (1996)

669 Generalized model for N2 and N2O production from nitrification and denitrification. Glob

670 biogeochem cycles 10(3):401-412. doi:10.1029/96GB01455

671 Penman HL (1948) Natural evaporation from open water, bare soil and grass. Proc R Soc

672 Lond A: Mathematical and Physical Sciences 193(1032):120-145.

673 Pugnaire FI, Serrano LUIS, Pardos, JOSE (1999) Constraints by water stress on plant growth.

674 In: Pugnaire FI, Valladares F (eds) Handbook of functional plant ecology. CRC Press, New

675 York, pp 271-283. 
676 Ravi S, Breshears DD, Huxman TE, D'Odorico P (2010) Land degradation in drylands:

677 Interactions among hydrologic-aeolian erosion and vegetation dynamics. Geomorphology

678 116(3):236-245. doi:10.1016/j.geomorph.2009.11.023

679 Reichstein M, Bahn M, Ciais P, Frank D, Mahecha MD, Seneviratne SI, Zscheischler J, Beer

680 C, Buchmann N, Frank DC, Papale D, Rammig A, Smith P, Thonicke K, Velde M, Vicca S,

681 Walz A, Wattenbach M (2013) Climate extremes and the carbon cycle. Nature 500(7462):287-

682 295. doi:10.1038/nature 12350

683 Sala OE, Parton WJ, Joyce LA, Lauenroth WK (1988) Primary production of the central

684 grassland region of the United States. Ecology 69(1): 40-45. doi:10.2307/1943158

685 Saxton KE, Rawls W, Romberger JS, Papendick RI (1986) Estimating generalized soil-water

686 characteristics from texture. Soil Sci Soc Am J 50(4):1031-1036.

687 Saxton KE, Rawls WJ (2006) Soil water characteristic estimates by texture and organic matter

688 for hydrologic solutions. Soil Sci Soc Am J, 70(5), 1569-1578. doi:10.2136/sssaj2005.0117

689 Schulze ED, Beck E, Müller-Hohenstein K (2005) Environment as Stress Factor: Stress

690 Physiology of Plants. Plant Ecol 702(9): 506.

691 Shao Y (2008) Physics and modelling of wind erosion (2nd). Springer.

692 Shao Y, Dong CH (2006) A review on East Asian dust storm climate, modelling and

693 monitoring. Glob Planet Chang 52(1-4): 1-22. doi:10.1016/j.gloplacha.2006.02.011 
694 Shao Y, Raupach MR, Findlater PA (1993) Effect of saltation bombardment on the

695 entrainment of dust by wind. J Geophys Res Atmos 98(D7):12719-12726.

696 doi:10.1029/93JD00396

697 Shao Y, Wyrwoll KH, Chappell A, Huang J, Lin Z, McTainsh GH, Mikami M, Tanaka TY,

698 Wang X, Yoon S (2011) Dust cycle: An emerging core theme in Earth system science. Aeo

699 Res 2(4):181-204. doi:10.1016/j.aeolia.2011.02.001

700 Shinoda M, Gillies JA, Mikami M, Shao Y (2011) Temperate grasslands as a dust source:

701 Knowledge, uncertainties, and challenges. Aeo Res 3(3):271-293.

702 doi:10.1016/j.aeolia.2011.07.001

703 Shinoda M, Kimura R, Mikami M, Tsubo M, Nishihara E, Ishizuka M, Tamada Y,

704 Munkhtsetseg E, Jugder D, Kurosaki Y (2010) Characteristics of dust emission in the

705 Mongolian steppe during the 2008 DUVEX intensive observational period. Sola 6:9-12.

706 doi:10.2151/sola.2010-003

707 Shinoda M, Nandintsetseg B, Nachinshonhor UG, Komiyama H (2014) Hotspots of recent

708 drought in Asian steppes. Reg Environ Chang 14(1):103-117. doi:10.1007/s10113-013-0464-0

709 Smika DE, Haas HJ, Power JF (1965) Effects of Moisture and Nitrogen Fertilizer on Growth

710 and Water Use by Native Grass. Agro J 57(5):483-486.

711 doi:10.2134/agronj1965.00021962005700050024x 
712 Sugita M, Asanuma J, Tsujimura M, Mariko S, Lu M, Kimura F, Azzaya D, Adyasuren T

713 (2007) An overview of the rangelands atmosphere-hydrosphere-biosphere interaction study

714 experiment in northeastern Asia (RAISE). J hydrol 333(1):3-20.

715 doi:10.1016/j.jhydrol.2006.07.032

716 Újvári G, Kok JF, Varga G, Kovács J (2016) The physics of wind-blown loess: Implications

717 for grain size proxy interpretations in Quaternary paleoclimate studies. Earth-Sci Rev 154:

718 247-278. doi:10.1016/j.earscirev.2016.01.006

719 UNCCD (1994) United Nations convention to combat desertification in countries

720 experiencing serious drought and/or desertification, particularly in Africa. A/AC.241/27, Paris

721 Van Heemst HDJ (1986) Physiological principles. In: Keulen H, Wolf J (eds) Modelling of

722 agricultural production: weather, soils and crops. Pudoc, Wageningen, pp 13-26.

723 Van Oost K, Quine TA, Govers G, De Gryze S, Six J, Harden JW, Ritchie JC, McCarty GW,

724 Heckrath G, Kosmas C, Giraldez JV, Marques da Silva JR, Merckx R (2007) The impact of

725 agricultural soil erosion on the global carbon cycle. Science 318(5850):626-629.

726 doi:10.1126/science.1145724

727 Wang X, Oenema O, Hoogmoed WB, Perdok UD, Cai D (2006) Dust storm erosion and its

728 impact on soil carbon and nitrogen losses in northern China. Catena 66(3):221-227.

729 doi:10.1016/j.catena.2006.02.006 
730 Yan Y, Wang X, Guo Z, Chen J, Xin X, Xu D, Yan R, Chen B, Xu L (2018) Influence of wind

731 erosion on dry aggregate size distribution and nutrients in three steppe soils in northern China.

732 Catena 170: 159-168. doi:10.1016/j.catena.2018.06.013

733 Yao S, Zhang T, Zhao C, Liu X (2013) Saturated hydraulic conductivity of soils in the Horqin

734 Sand Land of Inner Mongolia, northern China. Environ monit assess 185(7): 6013-6021.

735 doi:10.1007/s10661-012-3002-5

736 Yang Y, Fang J, Pan Y, Ji C (2009) Aboveground biomass in Tibetan grasslands. J Arid

737 Environ 73(1):91-95. doi:10.1016/j.jaridenv.2008.09.027

738 Zhang J, Teng Z, Huang N, Guo L, Shao Y (2016) Surface renewal as a significant

739 mechanism for dust emission. Atmos Chem Phys 16(24): 15517-15528. doi:10.5194/acp-16-

$740 \quad 15517-2016$

741 Zhao H, Yi X, Zhou R, Zhao X, Zhang T, Drake S (2006) Wind erosion and sand

742 accumulation effects on soil properties in Horqin Sandy Farmland, Inner Mongolia. Catena

743 65(1):71-79. doi:10.1016/j.catena.2005.10.001 


\section{Figures legends}

745 Figure 1. The steppe (Bayan-Unjuul, BU) and the desert steppe (Tsogt-Ovoo, TsO) grassland

746 sites in Mongolia and the different vegetation zones.

747 Figure 2. (a1 and a2) Time series of daily precipitation, and comparison of the daily observed

748 (depth $0.1 \mathrm{~m}$ ) and simulated (depth $0.075 \mathrm{~m}$ ) soil moisture, and (b1 and b2) the daily observed

749 and simulated above-ground mass (AGM, live plus standing dead grasses) at BU from 2002

750 to 2011 at TsO and from 2002 to 2016 at BU. Asterisks following the correlation coefficient

751 (*) indicate significance at the $95 \%$ level.

752 Figure 3. Monthly precipitation and air temperature (a1 and a2) and the monthly simulated

$753 W_{\text {stress }}, T_{\text {stress }}, N_{\text {stress }}$ and $A G P_{\text {act }}$ for the actual condition and the wind-eroded scenario during

754 the growing season (May-September) from 2002 to 2011 at TsO (b1 and c1) and BU (b2 and

755 c2), respectively.

756 Figure 4 . The monthly differences in $A G P_{a c t}\left(\mathrm{a} 1\right.$ and a2), $W_{\text {stress }}\left(\mathrm{b} 1\right.$ and b2), and $N_{\text {stress }}(\mathrm{c} 1$ and

$757 \mathrm{c} 2)$ between the actual condition and the wind-eroded scenario ( $\triangle A G P_{\text {act }}, \Delta W_{\text {stress }}$, and $\left.\Delta N_{\text {stress }}\right)$

758 (a1-c1, a2-c2) and the number of months when plant growth experienced water and nitrogen

759 stresses (d1, d2), during the critical growing season (June-August) from 2002 to 2011 at TsO

760 and BU, respectively.

761 Figure 5. Schematic representation of the different mechanisms that drove the changes in

762 plant production in wind-eroded coarse-textured topsoil on the desert steppe (TsO, from a1 to 
a5) and the steppe (BU, from b1 to b5) because of the inverse texture effect. The different-

764 sized (thick and thin) arrows indicate the magnitude (high and low) of the variables

765 (precipitation, ET: evapotranspiration, and infiltration).

\section{Tables}

768 Table 1. Model parameterizations of the vegetation, soil, and meteorological characteristics

\begin{tabular}{|c|c|c|}
\hline Parameter & BU & TsO \\
\hline Potential above-ground monthly production $\left(\mathrm{gC} \mathrm{m}^{-2}\right)$ & $300 *$ & $100^{*}$ \\
\hline Optimum temperature for steppe $\left({ }^{\circ} \mathrm{C}\right)$ & $20.0 *$ & $22.0 *$ \\
\hline Maximum temperature for steppe $\left({ }^{\circ} \mathrm{C}\right)$ & $35.0 *$ & $37.0 *$ \\
\hline $\begin{array}{l}\text { Physiological shoutdown temperature for root death and change } \\
\text { in shoot/root ratio of grass }\left({ }^{\circ} \mathrm{C}\right)\end{array}$ & $2.0^{*}$ & \\
\hline $\begin{array}{l}\text { Maximum shoot death rate at very dry soil conditions for steppe } \\
(0-1)\end{array}$ & $0.2^{*}$ & \\
\hline Shoots which die during senescence month $(0-1)$ & $0.95^{*}$ & \\
\hline The maximum root death rate at very dry conditions for steppe & $0.05^{*}$ & \\
\hline The thickness of soil layers (m) & $0.3(\mathrm{a})$ & $0.4(\mathrm{a})$ \\
\hline Soil pH (topsoil) & $6.5(a)$ & $8.17(\mathrm{a})$ \\
\hline Root depth (m) & $0.4(\mathrm{a})$ & $0.4(\mathrm{a})$ \\
\hline
\end{tabular}




\begin{tabular}{|c|c|c|}
\hline Soil field capacity (topsoil) $(0-1)$ & $0.21(\mathrm{a})$ & $0.23(\mathrm{a})$ \\
\hline Soil wilting point (topsoil) $(0-1)$ & $0.07(\mathrm{a})$ & $0.10(a)$ \\
\hline Soil bulk density (topsoil) $\left(\mathrm{g} \mathrm{cm}^{-3}\right)$ & $1.44(a)$ & 1.49 (a) \\
\hline Clay content (topsoil) $(0-1)$ & $0.09(\mathrm{a})$ & $0.17(\mathrm{a})$ \\
\hline Sandy content (topsoil) $(0-1)$ & $0.65(\mathrm{a})$ & $0.64(a)$ \\
\hline Silt content (topsoil) $(0-1)$ & $0.24(\mathrm{a})$ & $0.19(a)$ \\
\hline Initial belowground biomass $\left(\mathrm{g} \mathrm{m}^{-2}\right)$ & \multicolumn{2}{|l|}{$200 *$} \\
\hline Initial relative soil moisture content $(0-1)$ & \multicolumn{2}{|l|}{$0.16^{*}$} \\
\hline Annual precipitation (mm) & \multirow{3}{*}{\multicolumn{2}{|c|}{ (b) }} \\
\hline Daily minimum air temperature $\left({ }^{\circ} \mathrm{C}\right)$ & & \\
\hline Daily maximum air temperature $\left({ }^{\circ} \mathrm{C}\right)$ & & \\
\hline Standing dead removed by a grazing event & $0.01(\mathrm{a})$ & $0.05(\mathrm{c})$ \\
\hline Content of feces & \multicolumn{2}{|l|}{$0.25^{*}$} \\
\hline Live shoots removed by a grazing event & $0.1(a)$ & $0.5(a)$ \\
\hline
\end{tabular}

* From DAYCENT data-setting (around the world);

770 (a) Observation data at BU (Nandintsetseg and Shinoda, 2015) and at TsO, mean parameters

771 were related to the vegetation and soil types

772 (b) Meteorological data from IRIMHE;

773 (c) Analogizing with live shoots removed by a grazing event at BU and TsO. 
775 Table 2. The number of months when different controls affected plant production during the

776 growing season from 2002 to 2011

\begin{tabular}{|c|c|c|c|c|c|c|c|c|c|}
\hline & \multirow{3}{*}{ location } & \multicolumn{4}{|c|}{$\Delta \mathbf{A G P}_{\text {act }}<\mathbf{0}$} & \multicolumn{4}{|c|}{$\Delta \mathbf{A G P a c t}>\mathbf{0}$} \\
\hline & & $\Delta \mathrm{W}>0$ & $\Delta \mathrm{W}>0$ & $\Delta \mathrm{W}>0$ & $\Delta \mathrm{W}<0$ & $\Delta \mathrm{W}>0$ & $\Delta \mathrm{W}<0$ & $\Delta \mathrm{W}<0$ & $\Delta \mathrm{W}<0$ \\
\hline & & $\Delta \mathrm{N}>0$ & $\Delta \mathrm{N}=0$ & $\Delta \mathrm{N}<0$ & $\Delta \mathrm{N}>0$ & $\Delta \mathrm{N}<0$ & $\Delta \mathrm{N}>0$ & $\Delta \mathrm{N}=0$ & $\Delta \mathrm{N}<0$ \\
\hline \multirow[t]{2}{*}{ Months } & BU & 1 & 0 & 7 & 2 & 5 & 14 & 0 & 1 \\
\hline & $\mathrm{TsO}$ & 0 & 28 & 0 & 0 & 0 & 0 & 2 & 0 \\
\hline
\end{tabular}

$777 \Delta \mathrm{AGP}_{\text {act }}, \Delta \mathrm{W}$, and $\Delta \mathrm{N}$ : The differences in the actual plant production, water stress, and

778 nitrogen stress between the actual condition and the wind-eroded scenario. 


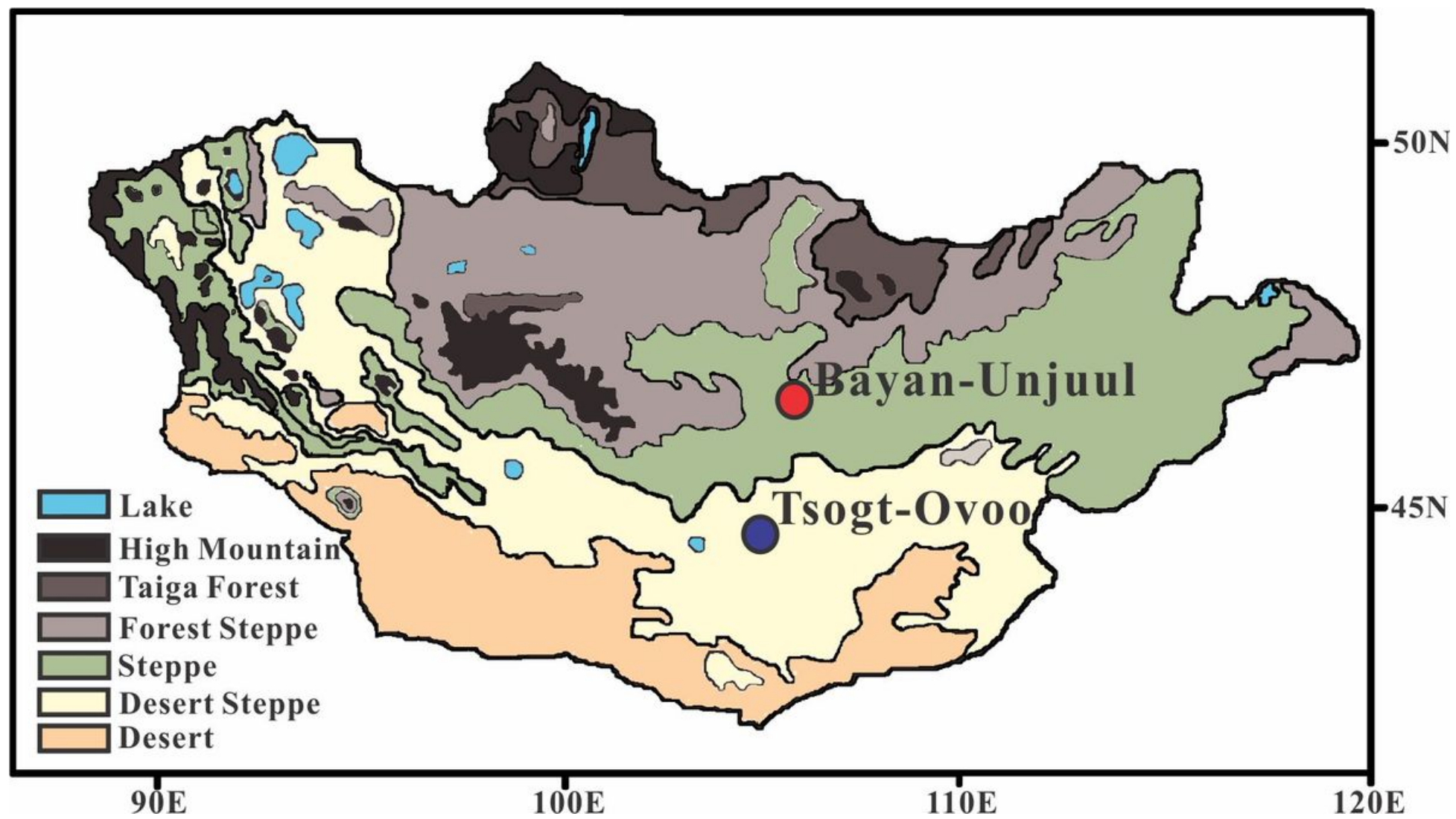

Figure 1

The steppe (Bayan Unjuul, BU) and the desert steppe (Tsogt Ovoo, TsO) grassland sites in Mongolia and the different vegetation zones.

\section{TsO}

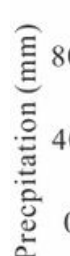$$
\text { (a1) }
$$$$
\text { 二 Precipitation } 2 \text { Simulation (Soil Water) }
$$$$
40 \text { - Observation (Soil Water) }
$$$$
0
$$

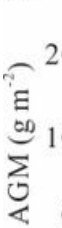$$
\text { (b1) }
$$

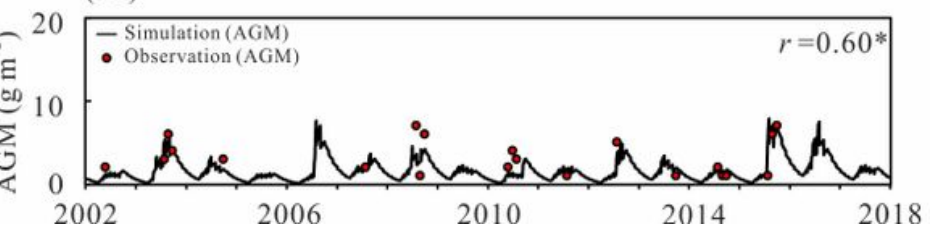

\section{Figure 2}

(a1 and a2) Time series of daily precipitation, and comparison of the daily observed (depth $0.1 \mathrm{~m}$ ) and simulated (d epth $0.075 \mathrm{~m}$ ) soil moisture, and (b1 and b2) the daily observed and simulated above ground mass AGM , live plus standing dead grasses ) at BU from 2002 to 2011 at TsO and from 2002 to 2016 at BU . Asterisks following the correlation coefficient $\left(^{*}\right)$ indicate significance at the $95 \%$ level. 
TsO

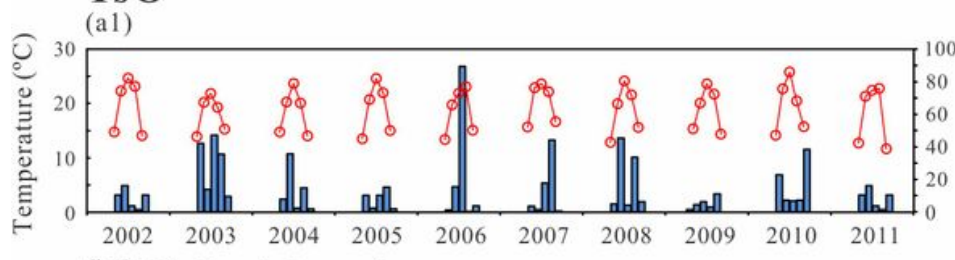

(b1) Wind-eroded scenario

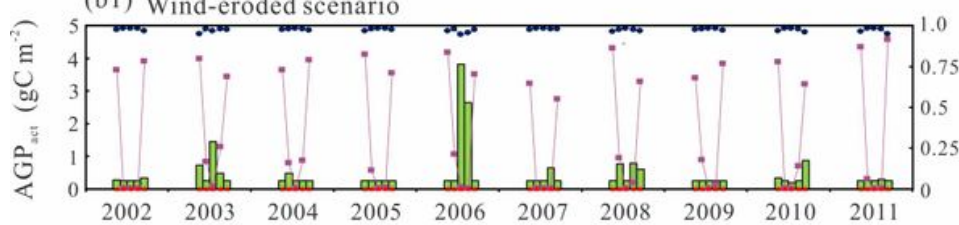

(c1) Actual condition

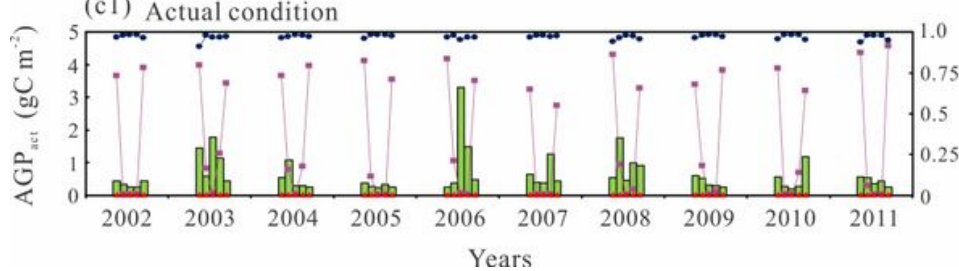

BU
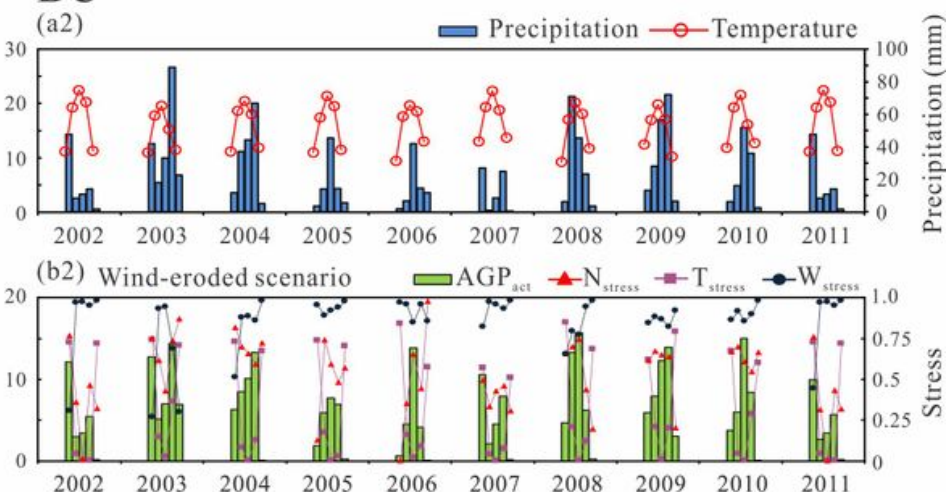

(c2) Actual condition

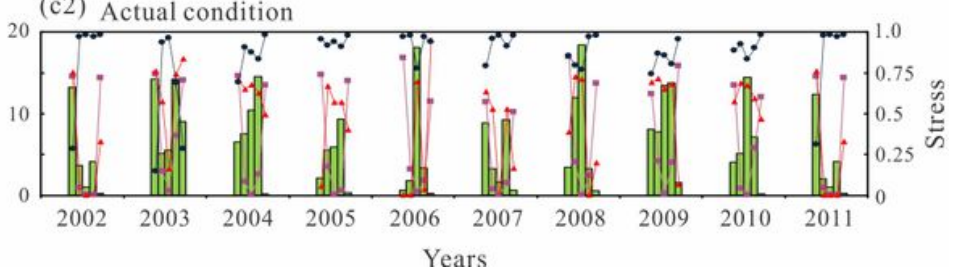

\section{Figure 3}

Monthly precipitation and air temperature (a1 and a2) and the monthly simulated W stress, $\mathrm{T}$ stress , N stress and AGP act for the actual condition and the wind eroded scenario during the growing season (May September) fro m 2002 to 2011 at TsO (b1 and c1) and BU (b2 and c2), respectively

\section{TsO}

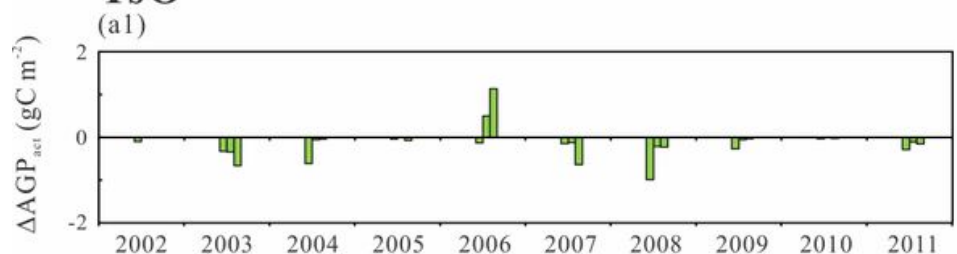

(b1)

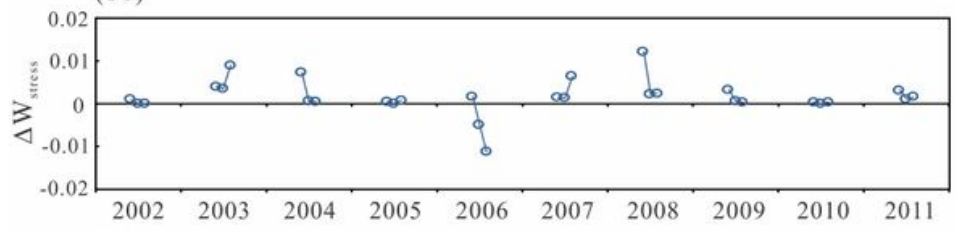

(c1)

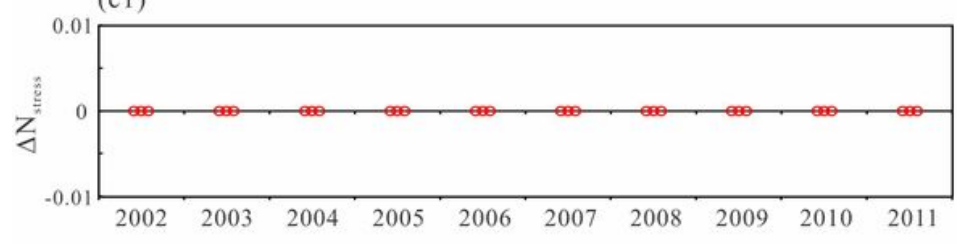

(d1)

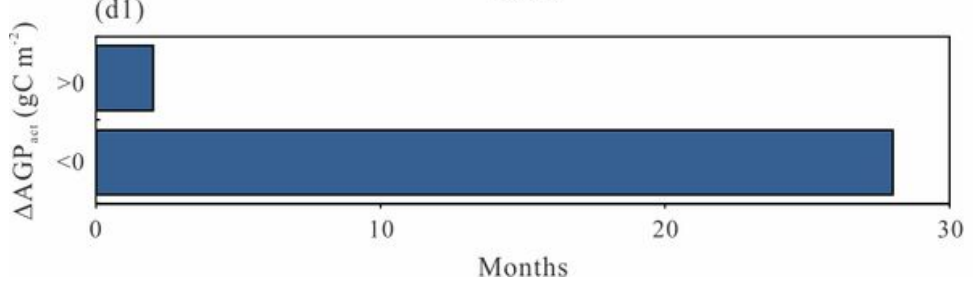

BU

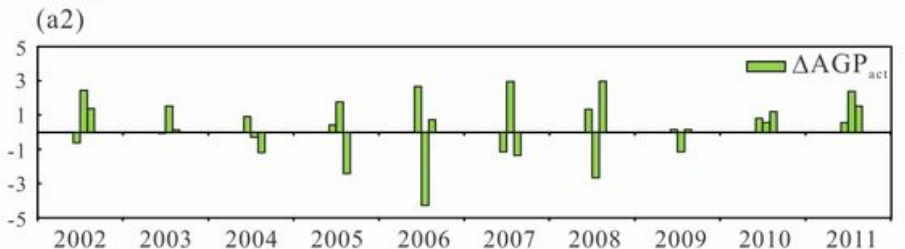

(b2)

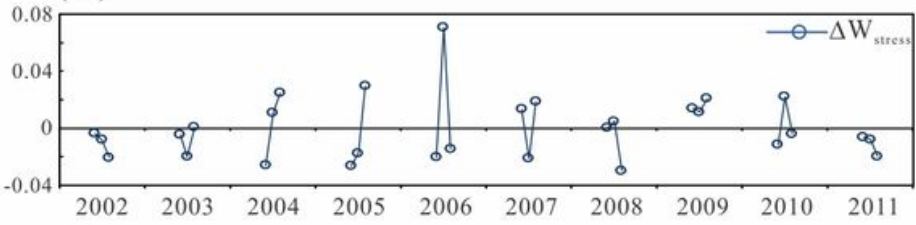

(c2)

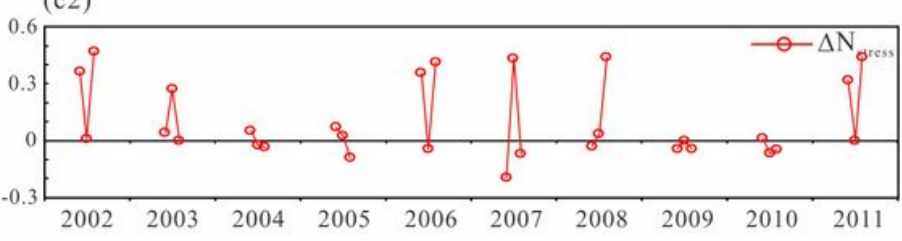

(d2)

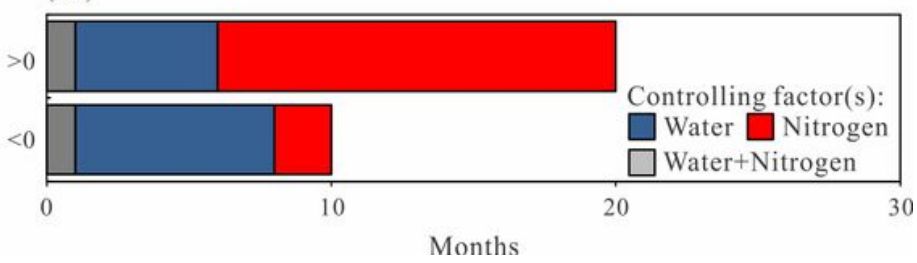

Figure 4 
The monthly differences in AGP act ( $\mathrm{a} 1$ and $\mathrm{W}$ stress (b1 and b2), and $\mathrm{N}$ stress ( $\mathrm{c} 1$ and $\mathrm{c} 2$ ) between the actual condition and the wind eroded scenario ( ( $\triangle \mathrm{AGP}$ act , $\Delta \mathrm{W}$ stress, and $\Delta \mathrm{N}$ stress ) (a1 c1, a $2 \mathrm{c} 2)$ and the number of months when plant growth experienced water and nitrogen stresses (d1, d2), during the critical growing season (June August) from 2002 to 2011 at TsO and BU, respectively.

Drier desert steppe

Precipitation

Wind-eroded scenario Actual condition

(a1)

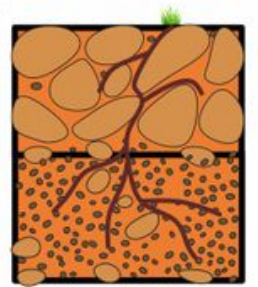

(a2)

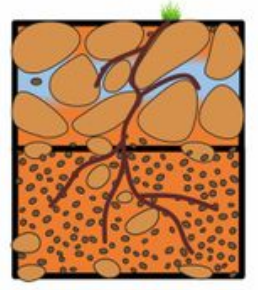

(a3)

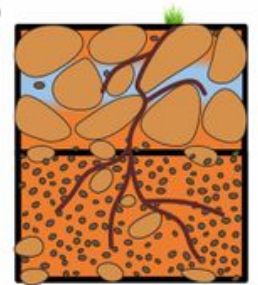

(a4)

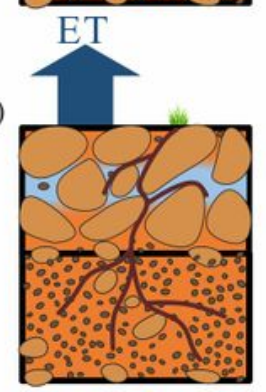

(a5)

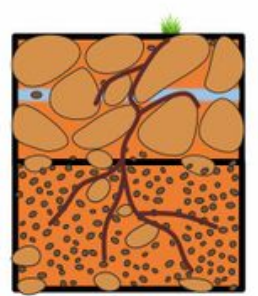

Root-Zone Water $(\downarrow)$
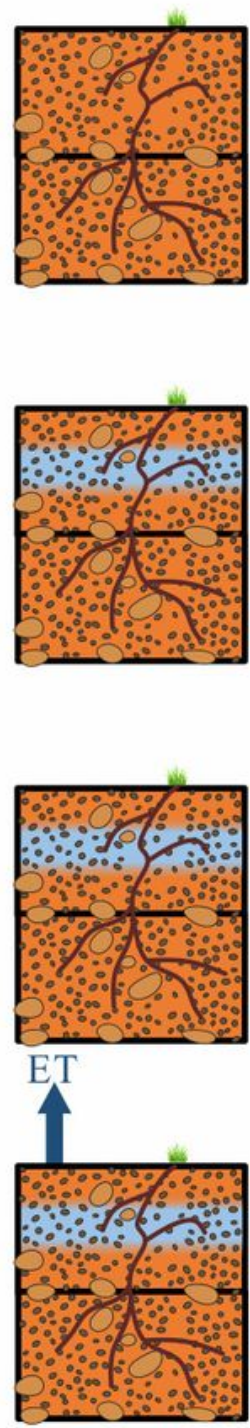

Higher AGP

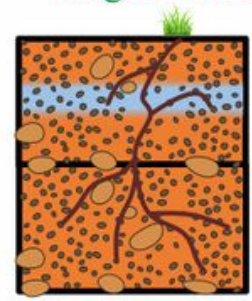

Root-Zone Water $(\uparrow)$
Wetter steppe

Precipitation

Wind-eroded scenario Actual condition

(b1)
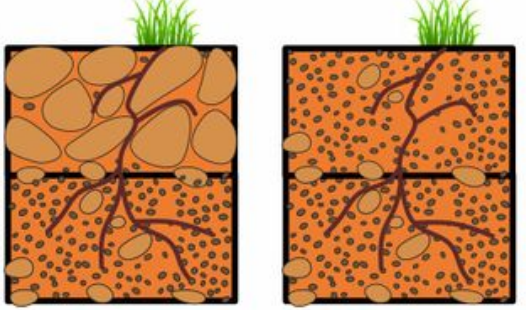

(b2)
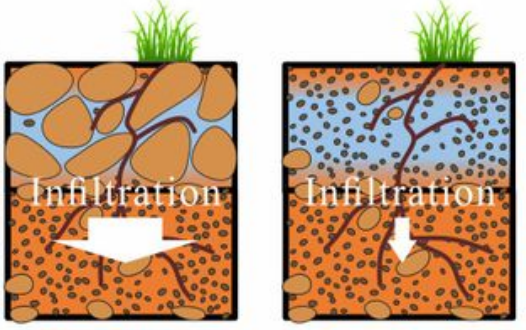

(b3)

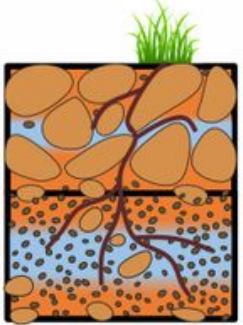

(b4)
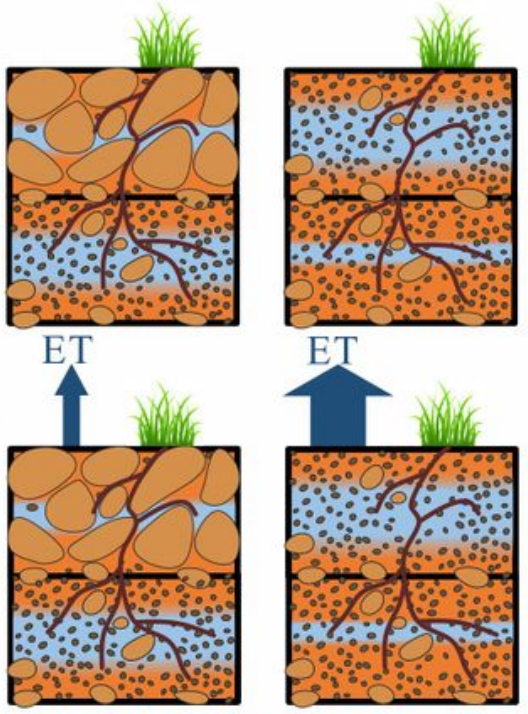

Higher AGP

(b5)

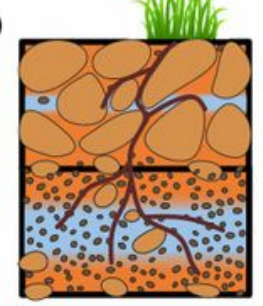

Root-Zone Water $(\uparrow)$

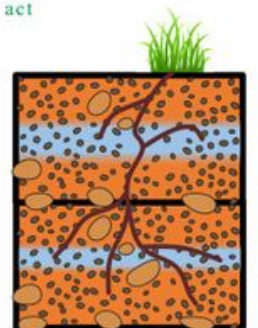

Root-Zone Water $(\downarrow)$

Figure 5 
Schematic representation of the different mechanisms that drove the changes in plant production in wind eroded coarse textured topsoil on the desert steppe ( $\mathrm{TsO}$, from a1 to a5) and the steppe(BU, from b1 to b5) because of the inverse texture effect. The different sized (thick and thin) arrows indicate the magnitude (high and low) of the variables (precipitation, ET: evapotranspiration, and infiltration).

\section{Supplementary Files}

This is a list of supplementary files associated with this preprint. Click to download.

- AbsFig20200326.jpg 